\title{
Autoantibody against IA-2 Improves the Test Sensitivity for Insulin-Dependent Diabetes Mellitus in Japanese Patients of Child Onset
}

\author{
AKIRA KASUGA*,**, YuKako OZAWA*, TARo MARUYAMA***, ToshihIde ISHIHARA****, \\ SHIN AMEMIYA****, AND TAKAO SARUTA* \\ *Department of Internal Medicine, Keio University School of Medicine, Tokyo 160, \\ **Department of Internal Medicine, Tokyo Denryoku Hospital, Tokyo 160, \\ ***Department of Internal Medicine, Social Insurance Saitama Chuo Hospital, Saitama 336, and \\ ****Department of Pediatrics, Yamanashi Medical University, Yamanashi, 409-36, Japan
}

\begin{abstract}
We previously reported that IA-2 autoantibodies (Ab) facilitated the diagnosis of Japanese insulin-dependent diabetes mellitus (IDDM), but the number tested was not large enough to investigate whether IA-2Ab can improve the diagnostic accuracy. In this report, sera from 78 patients with less than 2 year-disease duration (the mean (range) ages were $19.2(6-52)$ years old) were tested in order to clarify that the combination of IA-2Ab and glutamic acid decarboxylase 65 (GAD65)Ab would improve the test sensitivity for IDDM. Both of the autoantibodies were frequently detected in Japanese abrupt-onset IDDM but the frequency of GAD65Ab was higher than that of IA-2Ab $(69 \%$ and $47 \%$, respectively, $P=0.024$ ). The two autoantibodies were discordant in respect to both positivity and titer. The positivity for IA-2Ab decreased with the increasing onset-age of the patients $(76,47,37,21 \%$ for each quartile of age tested), but the frequency of GAD65Ab was unaffected. Among the youngest quartile ( $\leq 12$ years old), IA-2Ab, in combination with GAD65Ab, significantly improved sensitivity $(68 \%$ to $92 \%, P<0.05)$, but when we tested patients over 12 years old, IA-2Ab caused little, if any, improvement in sensitivity. We confirmed that IA-2 antibody was detected in IDDM among Japanese, as seen in Caucasians, but the test sensitivity was improved only in young IDDM patients among Japanese.
\end{abstract}

Key words: IA-2, GAD65, IDDM, Sensitivity, Radioligand binding assay

(Endocrine Journal 44: 485-491, 1997)

INSULIN-DEPENDENT diabetes mellitus (IDDM) is considered to be an autoimmune disorder in which pancreatic beta cell destruction occurs in a genetically susceptible host [1]. A growing number of autoantibodies reactive with islet antigens have been described, such as islet cell antibodies (ICA) [2], and autoantibody against insulin [3], the 65,000 Mr. isoform of glutamic acid decarboxylase $(\mathrm{GAD} 65 \mathrm{Ab})[4,5]$, heat shock protein 60 [6], islet

Received: October 30, 1996

Accepted: March 28, 1997

Correspondence to: Dr. Akira KASUGA, Department of Internal Medicine, Tokyo Denryoku Hospital, Shinanomachi 9-2, Shinjuku-ku, Tokyo 160, Japan cell antigen 69 [7], carboxypeptidase $\mathrm{H}$ [8], and a GM2-1 ganglioside [9].

Recently, antibodies to Mr. 37,000/40,000 tryptic fragments of the islet cell protein were reported to be detected in IDDM [10] and prediabetic twins [11]. In addition, Bingley et al. reported that these antibodies improve the prediction of IDDM of islet cell antibody-positive relatives [12]. We previously reported that these antibodies were also detected in Japanese [13], but assay for antibodies to the Mr. 37,000/40,000 tryptic fragments is difficult for general use since the antigens are expressed at low levels in pancreatic islets and insulinoma cells [14].

One of the receptor-type protein tyrosine phosphatases was cloned from pancreatic islets 
cells, named islet cell antigen 512 (ICA512) [15, 16] or IA-2 [17], and reported to be a target antigen for the Mr. 37,000/40,000 tryptic fragments of the islet cell protein [14, 18, 19] and ICA [19, 20]. Our previous report indicated that autoantibody to IA2 (IA-2Ab) was titrated by a sensitive radioligand binding assay [21] and might be discordant with GAD65Ab [13]. Because of the small number studied, it is not clear whether the combination of the two antibodies is a good screening test for a large population.

In this study, we first compared the frequency and titer of GAD65Ab with those of IA-2Ab in order to confirm the discordance of the two antibodies in IDDM in Japanese patients. Second, we investigated whether age affects the positivity of IA-2Ab, as seen in Caucasians and whether IA$2 \mathrm{Ab}$ improves the diagnostic value in combination with GAD65Ab.

\section{Material and Methods}

\section{Patients' sera (Table 1)}

Sera from 78 IDDM patients, with less than a two year-disease duration, were collected from our hospitals. These patients fulfilled the criteria for IDDM [22] with ketoacidosis at onset. They were further divided into quartiles according to the onset age. Seventy-eight sera from healthy individuals were also included in the study. All subjects gave informed consent for this study, which was approved by the Ethical Committee at Keio University, Tokyo, Japan. All sera were kept frozen at $-80^{\circ} \mathrm{C}$ and all assays were performed on coded samples.

\section{Assay for GAD65 and IA-2}

Autoantibodies against GAD65 or IA-2 were detected using the previously described radioligand binding assay $[23,24]$. Briefly, a clone of the fulllength human islet GAD65 (clone pEx9, kindly provided by Drs. Allan E. Karlsen and Catherine E. Grubin, University of Washington, Seattle, USA, [25]) or the carboxyl part (aa 256-979) of full length human IA-2 [21, 26] (clone ICA512.bdc, kindly provided by Prof. George S. Eisenbarth, the Barbara Davis Center for Childhood Diabetes, University of Colorado Health Center, Denver, USA) was used
Table 1. Characteristics of the study group

\begin{tabular}{lccc}
\hline & & IDDM & Control \\
\hline Female/Male & & $47 / 31$ & $40 / 38$ \\
Mean age ( \pm SD) & (year old) & $19.2 \pm 10.0$ & $20.6 \pm 2.5$ \\
Range & (year old) & $6-52$ & $16-50$ \\
Disease duration (months) & $8.8 \pm 9.5$ & \\
\hline
\end{tabular}

in an in vitro transcription and translation reaction to produce ${ }^{35} \mathrm{~S}-\mathrm{GAD} 65$ or ${ }^{3} \mathrm{H}-\mathrm{IA}-2$ respectively. The labeled proteins in duplicate were diluted in $48 \mu l$ of immunoprecipitation buffer $(20 \mathrm{mmol} / \mathrm{L}$ Tris, $150 \mathrm{mmol} / \mathrm{L} \mathrm{NaCl}, 0.15 \%(\mathrm{v} / \mathrm{v}$ ) Tween $20,0.1 \%$ $(\mathrm{w} / \mathrm{v})$ Aprotinin and $10 \mathrm{mmol} / \mathrm{L}$ benzamidine, $\mathrm{pH}$ 7.4) before the addition of $2 \mu l$ of either the serum sample or a positive or a negative standard serum (final serum dilution 1:25). After overnight incubation at $4{ }^{\circ} \mathrm{C}$ on a rotating platform, the antibody-bound labeled protein was separated from the free antigen by the addition of $50 \mu l 50 \%$ (v/v) protein A-Sepharose. After washes in $200 \mu l$ immunoprecipitation buffer, the Sepharose beads were collected into glass vials containing $4 \mathrm{ml}$ scintillation fluid and the immunoprecipitated radioactivity was determined in a liquid scintillation analyzer. With a positive IDDM and negative healthy standard sera, the levels of GAD65Ab or IA-2Ab were expressed as the index: (Unknown sample-Mean of three negative standard sera) / (Positive standard serum-Mean of negative standard sera).

The upper level of normal of the GAD65Ab assay was estimated to be 0.020 [27]. Intra- and inter assay coefficient variations were $3.2 \%$ and $4.4 \%$ for GAD65Ab (index 0.623). In the First Combinatorial Autoantibody Workshop (Immunology of Diabetes Society, 1995), our GAD65Ab assay showed 74.4\% sensitivity and $98.0 \%$ specificity. At the workshop, the sensitivity of GAD65Ab in the radioligand assays varied between 54.5 and $76.5 \%$ (51 IDDM patients) among 23 laboratories with 95-99\% specificity (100-101 healthy controls).

The IA-2Ab index was also normally distributed among healthy Japanese individuals, so that the upper level of normal of the IA-2Ab assay was estimated to be 0.010 (mean $+3 S D)$. The Receiver Operating Characteristic plots also support this cut off level. Intra- and inter assay coefficient variations were $4.5 \%$ and $4.2 \%$ (index 0.528 ). With the serum kit for the First Combinatorial 
Table 2. Effects of age on the autoantibodies among IDDM

\begin{tabular}{lcccccc}
\hline & Control & All & \multicolumn{4}{c}{ (onset age) } \\
& & & $\leq 12$ & $13-15$ & $16-25$ & $\geq 26$ \\
\hline GAD65Ab only & $1(1 \%)$ & $26(33 \%)$ & 4 & 6 & 7 & 9 \\
IA-2Ab only & $1(1 \%)$ & $9(12 \%)$ & 6 & 2 & 1 & 0 \\
Both & $0(0 \%)$ & $28(36 \%)$ & 13 & 5 & 6 & 4 \\
None & $76(98 \%)$ & $15(19 \%)$ & 2 & 2 & 5 & 6 \\
\hline Total & 78 & 78 & 25 & 15 & 19 & 19 \\
\hline
\end{tabular}

Autoantibody Workshop, our IA-2Ab assay showed $60.5 \%$ sensitivity and $98.0 \%$ specificity. At the workshop, the sensitivity of ICA512/IA-2 autoantibodies in the radioligand assays varied between 56.8 and $72.5 \%$ among 12 laboratories with 95-99\% specificity.

\section{Statistical analyses}

The frequency of antibodies was tested by Fisher's exact test or corrected for onset age by the Mantel Haenszel Chi-square test. The degree of correlation between the two antibodies was expressed as the Phi-coefficient. The relationship between the titers of the two autoantibodies was tested by Pearson's correlation coefficient after log transformation. Probability less than 0.05 after correction for the number of tests (GAD65Ab and $\mathrm{IA}-2 \mathrm{Ab}$ ) was considered as statistically significant.

\section{Results}

Frequency of the autoantibodies in IDDM in Japanese patients

As shown in Table 2, GAD65Ab and IA-2Ab were each detected individually in two different healthy subjects $(1 / 78,1.3 \%)$. GAD65Ab was more frequently detected in 69\% (54/78) in Japanese abrupt-onset IDDM than in healthy subjects $(P<0.00001)$. The frequency of IA-2Ab was also higher than that of controls $(45 \%, 35 / 78$, $P<0.00001)$, which was significantly lower than that of GAD65Ab $(P=0.0017)$. Table 2 showed that the two tests were discordant for positivity among all patients tested, since 35 out of 78 patients had only either of the two autoantibodies (Chi-square $=0.857$, Phi-coefficient=0.133). The titers of the two

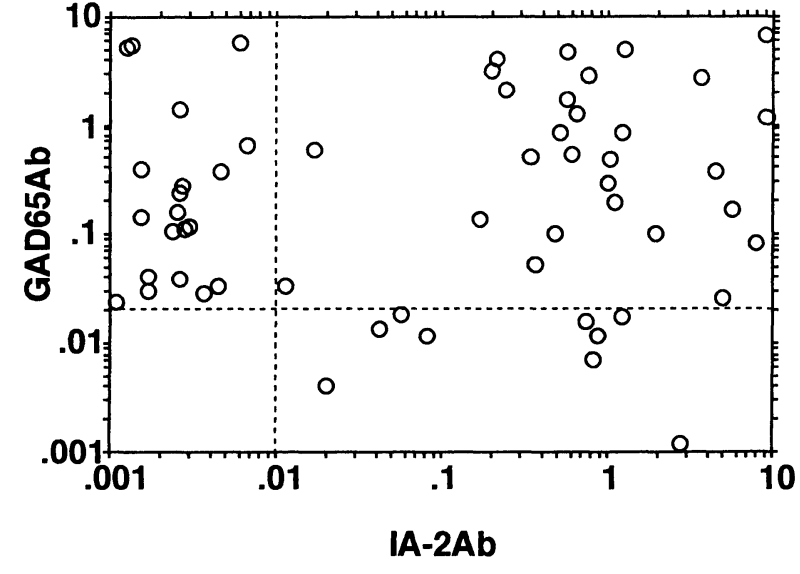

Fig. 1. Scattergram for titers of GAD65Ab and IA-2Ab. The titers of the two autoantibodies were not related $\left(r^{2}=0.023\right.$, N.S. $)$.

autoantibodies also had no significant correlation (Fig. 1, $\mathrm{r}^{2}=0.023$, N.S.).

Effect of age and disease duration on the frequency of the autoantibodies

The relationship between the age of onset and frequency of antibodies is shown in Fig. 2. GAD65Ab was detected in $68 \%$ of the youngest quartile of abrupt-onset IDDM and consistently observed among all quartiles of age. On the other hand, the frequency of IA-2Ab was $76 \%$ in the youngest but decreased with the increase in age $(47 \%, 37 \%, 21 \%$, for each quartile).

Table 3 showed the disease duration and positivity of the autoantibodies. The frequency of IA- $2 \mathrm{Ab}$ among the youngest quartile (equal to or less than 12 years old) with disease duration less than one year did not differ from patients with the disease for more than one year $(78.6 \%, 11 / 14$ and 
$72.7 \%, 8 / 11$, respectively). This was also observed in GAD65Ab $(71.4 \%, 10 / 14$ and $63.6 \%, 7 / 11)$. The Mantel Haenszel Chi-square test verified that both antibodies were detected with an insignificant difference between less than one-year and more than one-year of disease duration after correction for onset-age.

Adding the test results for IA-2Ab to those for

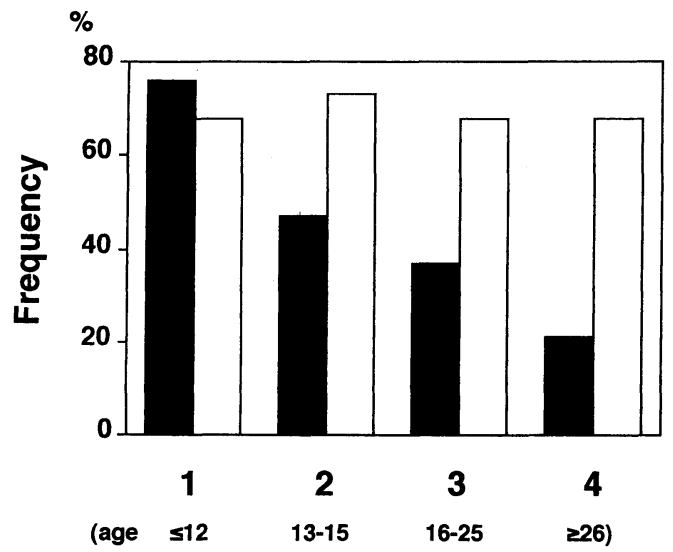

Fig. 2. Frequencies of GAD65Ab and $I A-2 A b$ according to patient's age. Shaded and unshaded bars indicate IA-2Ab and GAD65Ab, respectively. Numbers indicate quartiles of onset age. $1: \leq 12$ years old, $n=25,2: 13-15$ years old, $n=15,3: 16-25$ years old, $n=19,4: \geq 26$ years old, $n=19$. GAD65Ab was detected in $68 \%$ of the youngest quartile of abrupt-onset IDDM and consistently observed among all quartiles of age. On the other hand, the frequency of IA-2Ab was $76 \%$ in the youngest but decreased with the increase in age $(47 \%, 37 \%, 21 \%$, for each quartile).
GAD65Ab tended to improve the sensitivity among all patients $(69 \%, 54 / 78$ to $81 \%, 63 / 78)$ This improvement reached statistical significance in the youngest quartiles $(68 \%, 17 / 25$ to $92 \%, 23 / 25$, $P=0.020$ ), but when we tested the patients over 12 years old, IA-2Ab added little, if any, improvement in sensitivity.

\section{Discussion}

Antibodies to Mr. 37,000/40,000 tryptic fragments of the islet cell protein and their target antigen, ICA512 [15, 16], IA-2 [17, 18], or IA-2 beta [28], were reported to improve the ability to predict IDDM $[11,29]$. Because it was also reported that IA-2Ab and GAD65Ab can be measured with a single assay $[19,30]$, GAD65Ab, in combination with IA-2Ab, would replace ICA and be a good screening test for a large population [31].

In this study, we clarified that IA-2Ab was detected with a sensitive radioligand binding assay in $76 \%$ of young IDDM in Japanese patients $(\leq 12$ years old), comparable to the frequency reported in Caucasians $(51 \%$ of patients under the age of 20 years [20], 59\% of patients under the age of 15 years [19]). Our result showing that IA-2Ab was frequently detected among the patients with a disease duration of more than one year, differs from a previous report [20]. That report indicated that the frequency of IA-2Ab detected by ELISA was not significantly higher even among the younger IDDM patients with a disease duration of more than 1 month, in comparison with the healthy control subjects. Our report determined that IA-

Table 3. Duration and positivity for the autoantibodies among IDDM

\begin{tabular}{lllll}
\hline & $\leq 12$ & $13-15$ & $16-25$ & $\geq 26$ (onset age) \\
\hline $\begin{array}{l}\text { GAD65Ab } \\
\text { Disease duration }\end{array}$ & & & & \\
$\quad$ Onset & $0 \%(0 / 1)$ & $67 \%(2 / 3)$ & $64 \%(9 / 14)$ & $67 \%(6 / 9)$ \\
$\quad 0-12$ Months & $71 \%(10 / 14)$ & $89 \%(7 / 8)$ & $69 \%(11 / 16)$ & $60 \%(9 / 15)$ \\
13-24 Months & $64 \%(7 / 11)$ & $57 \%(4 / 7)$ & $66 \%(2 / 3)$ & $100 \%(4 / 4)$ \\
\hline & & & & \\
IA-2Ab & & & & \\
Disease duration & & & & \\
Onset & $100 \%(1 / 1)$ & $33 \%(1 / 3)$ & $21 \%(3 / 14)$ & $22 \%(2 / 9)$ \\
$\quad 0-12$ Months & $79 \%(11 / 14)$ & $38 \%(3 / 8)$ & $25 \%(4 / 16)$ & $20 \%(3 / 15)$ \\
13-24 Months & $73 \%(8 / 11)$ & $57 \%(4 / 7)$ & $100 \%(3 / 3)$ & $25 \%(1 / 4)$ \\
\hline
\end{tabular}


$2 \mathrm{Ab}$, as well as GAD65Ab, was similarly detected in patients with a disease duration of less and in those with a disease duration of more than 1 year. The discrepancy between the results of the two reports should be attributed to the higher sensitivity of the radioligand binding assay compared to ELISA [21]. For example, the lower IA-2Ab titer, which was not detected by ELISA, may have existed in sera from the long disease duration IDDM in the previous report.

We next confirmed the previous observation that GAD65Ab and IA-2Ab were discordant with respect to both the frequency and titer of the autoantibodies [11, 19-21, 29], which was also suggested in our previous report [13]. We also observed that the frequency of IA-2Ab constantly decreased with the increase in the patients' age, whereas GAD65Ab was detected at the same frequency regardless of age. This was so even at the onset of the disease ( $\leq 1$ month). This relationship also was observed in Caucasians by Bonifacio et al. who reported that IA-2Ab was detected in $59 \%$ of patients under the age of 15 years, while only $39 \%$ were over 15 years [19].

Thus, in this study, IA-2Ab in combination with GAD65 Ab significantly improved sensitivity in the youngest quartile ( $\leq 12$ years) of age tested. In contrast, only one of the 12 GAD65Ab-negative patients ( $\geq 16$ years), was positive for IA-2Ab, so that IA-2Ab added little, if any, improvement as to sensitivity.

In Japanese, approximately $20 \%$ of IDDM patients have a non-insulin-dependent stage and this type of IDDM has been referred to as slowly progressive IDDM [32]. Therefore, Japanese NIDDM patients are considered to be at risk of developing IDDM and are an adequate population for screening. Our previous report suggests that the test for GAD65Ab is a suitable marker for insulin-dependency in Japanese NIDDM patients [24]. Since patients with slowly progressive IDDM are frequently seen over the age of 15 years, the test for IA-2Ab did not improve sensitivity as seen in this study [33]. We shall further investigate whether the test for IA-2Ab in combination with that for GAD65Ab will improve the positive predictive value for insulin-dependency among Japanese NIDDM.

In conclusion, IA-2Ab autoantibody was frequently detected by the radioligand binding assay in IDDM in Japanese patients as well as Caucasians. We confirmed previous observations indicating that IA-2Ab is discordant with GAD65 $\mathrm{Ab}$ and is more frequently detected in younger patients. The test for IA- $2 \mathrm{Ab}$ in combination with that for GAD65Ab improves the test sensitivity for IDDM patients aged under 15 years old.

\section{Acknowledgments}

We specially thank Prof. Åke Lernmark (Department of Medicine, University of Washington, Seattle, USA) for his critical review of the manuscript. We are also grateful to Drs. Allan E. Karlsen and Catherine E. Grubin (University of Washington, Seattle, USA) and Prof. George S. Eisenbarth (the Barbara Davis Center for Childhood Diabetes, University of Colorado Health Center, Denver, USA) for providing human GAD65 and ICA512.bdc clones.

\section{References}

1. Eisenbarth GS (1986) Type 1 diabetes mellitus: A chronic autoimmune disease. $N$ Engl J Med 314: 1360-1368.

2. Bottazzo GF, Florin-Christensen A, Doniach D (1974) Islet-cell antibody in diabetes mellitus with autoimmune polyendocrine deficiencies. Lancet 2: 1279-1283.

3. Palmer J (1993) Use of humoral immune markers. Diabetes Rev 1: 104-115.

4. Bækkeskov S, Aanstoot HJ, Cristgau S, Reeiz A, Solimena M, Cascalho M, Folli F, Richter-Olesen $H$,
De Camilli P (1991) Identification of the 64K autoantigen in insulin-dependent diabetes as the GABA-synthesizing enzyme glutamic acid decarboxylase. Nature (Lond) 347: 151-156.

5. Falorni A, Grubin CE, Takei I, Shimada A, Kasuga A, Maruyama T, Ozawa Y, Kasatani T, Saruta T, Li L, Lernmark $\AA$ (1994) Radioimmunoassay detects the frequent occurrence of autoantibodies to the Mr 65,000 isoform of glutamic acid decarboxylase in Japanese insulin-dependent diabetes. Autoimmunity 19: 113-125. 
6. Ozawa Y, Kasuga A, Nomaguchi H, Maruyama T, Kasatani T, Shimada A, Takei I, Miyazaki J, Saruta $T$ (1996) Detection of autoantibodies to the pancreatic islet heat shock protein 60 in insulindependent diabetes mellitus. J Autoimmunity 9: 517-524.

7. Pietropaolo M, Castano L, Babu S, Buelow R, Martin S, Martin A, Powers A, Prochazka M, Naggert J, Leiter EH, Eisenbarth GS (1993) Islet cell autoantigen $69 \mathrm{kDa}$ (ICA69): Molecular cloning and characterization of a novel diabetes associated autoantigen. J Clin Invest 92: 359-371.

8. Castano L, Russo E, Zhou L, Lipes M, Eisenbarth GS (1991) Identification and cloning of a granule autoantigen (carboxypeptidase $\mathrm{H}$ ) associated with type 1 diabetes. J Clin Endocrinol Metab 73: 11971201.

9. Dotta F, Previti M, Lenti 1, Dionisi S, Casetta B, D'Erme M, Eisenbarth GS, DiMario U (1995) GM21 pancreatic islet ganglioside: identification and characterization of a novel islet-specific molecule. Diabetologia 38: 1117-1121.

10. Christie MR, Vohra G, Champagne P, Denis D, Delovitch TL (1990) Distinct antibody specificities to a $64-\mathrm{kD}$ islet cell antigen in type 1 diabetes as revealed by trypsin treatment. J Exp Med 172: 789794.

11. Christie MR, Tun RY, Lo SS, Cassidy D, Brown TJ, Hollands J, Shattock M, Bottazzo GF, Leslie RDG (1992) Antibodies to GAD and tryptic fragments of islet $64 \mathrm{~K}$ antigen as distinct markers for development of IDDM. Studies with identical twins. Diabetes 41: 782-787.

12. Bingley PJ, Christie MR, Bonifacio E, Bonfanti R, Shattock M, Fonte M-T, Bottazzo G-F, Gale EA (1994) Combined analysis of autoantibodies improves prediction of IDDM in islet cell antibodypositive relatives. Diabetes 43: 1304-1310.

13. Ozawa $Y$, Kasuga A, Maruyama T, Kitamura $Y$, Amemiya S, Ishihara T, Suzuki R, Saruta T (1996) Antibodies to the 37,000-Mr tryptic fragment of islet antigen are detected in Japanese Insulin-dependent Diabetes Mellitus patients. Endocr J 43: 615-620.

14. Payton MA, Hawkes CJ, Christie MR (1995) Relation of the 37,000- and 40,000-Mr tryptic fragments of islets antigens in insulin-dependent diabetes to the protein tyrosine phosphatase-like molecule IA-2 (ICA512). J Clin Invest 96: 1506-1511.

15. Rabin DU, Pleasic SM, Palmer-Drocker R, Shapiro JA (1992) Cloning and expression of IDDM-specific human autoantigens. Diabetes 41: 183-186.

16. Rabin DU, Pleasic SM, Shapiro JA, Yoo-Warren H, Oles J, Hicks JM, Goldstein DE, Rae PM (1994) Islet cell antigen 512 is a diabetes-specific islet autoantigen related to protein tyrosine phosphatases. J Immunology 152: 3183-3188.

17. Lan MS, Lu J, Goto Y, Notkins AL (1994) Molecular cloning and identification of a receptor-type protein tyrosine phosphatase, IA-2, from human insulinoma. DNA and cell Biology 13: 505-514.

18. Passini N, Larigan JD, Genovese S, Appella E, Sinigaglia F, Rogge L (1995) The 37/40-kilodalton autoantigen in insulin-dependent diabetes mellitus is the putative tyrosine phosphatase IA-2. Proc Natl Acad Sci USA 92: 9412-9416.

19. Bonifacio E, Lampasona V, Genovese S, Ferrari M, Bosi E (1995) Identification of protein tyrosine phosphatase-like IA-2 (islet cell antigen 512) as the insulin-dependent diabetes-related $37 / 40 \mathrm{~K}$ autoantigen and a target of islet-cell antibodies. $J$ Immunology 155: 5419-5426.

20. Myers MA, Rabin DU, Rowley MJ (1995) Pancreatic islet cell cytoplasmic antibody in diabetes is represented by antibodies to islet cell antigen 512 and glutamic acid decarboxylase. Diabetes 44: 12901295.

21. Gianani R, Rabin DU, Verge CF, Yu L, Babu SR, Pietropaolo M, Eisenbarth GS (1995) ICA512 autoantibody radioassay. Diabetes 44: 1340-1344.

22. National Diabetes Data Group (1979) Classification and diagnosis of diabetes mellitus and other categories of glucose intolerance. Diabetes 28: 10391057.

23. Falorni A, Örtqvist E, Persson B, Lernmark Å (1995) Radioimmunoassays for glutamic acid decarboxylase (GAD65) and GAD65 autoantibodies using ${ }^{35 S}$ or ${ }^{3} \mathrm{H}$ recombinant human ligands. I Immunolog Methods 186: 89-99.

24. Kasuga A, Maruyama T, Ozawa Y, Takei I, Falorni A, Lernmark $\AA$, Saruta T (1996) Antibodies to the $\mathrm{Mr}$ 65,000 isoform of glutamic acid decarboxylase are detected in non-insulin-dependent diabetes in Japanese. J Autoimmunity 9: 101-115.

25. Karlsen AE, Hagopian WA, Grubin CE, Dube $S$, Disteche CM, Adler DA, Barmeier H, Mathewes S, Grant FJ, Foster D, Lernmark $\AA$ (1991) Cloning and primary structure of a human islet isoform of glutamic acid decarboxylase from chromosome 10. Proc Natl Acad Sci USA 88: 8337-8341.

26. Verge CF, Gianani R, Kawasaki E, Yu L, Pietropaolo M, Jackson RA, Chase HP, Eisenbarth GS (1996) Prediction of type I diabetes mellitus in first degree relatives using a combination of insulin, glutamic acid decarboxylase and ICA512bdc/IA-2 autoantibodies. Diabetes 45: 926-933.

27. Kasuga A, Falorni A, Maruyama T, Ozawa Y, Grubin CE, Matsubara K, Takei I, Saruta T, Scheynius A, Lernmark $\AA$ (1996) HLA class II is associated with the frequency of glutamic acid decarboxylase Mr 65,000 autoantibodies in Japanese patients with insulin-dependent diabetes mellitus. Acta Diabetologica 33: 108-113.

28. Lu J, Li Q, Xie H, Chen Z-J, Borovitskaya AE, Maclaren NK, Notkins AL, Lan MS (1996) 
Identification of a second transmembrane protein tyrosine phosphatase, IA-2 beta, as an autoantigen in insulin-dependent diabetes mellitus: Precursor of the $37 \mathrm{kDa}$ tryptic fragment. Proc Natl Acad Sci USA 93: 2307-2311.

29. Bonifacio E, Genovese S, Braghi S, Bazzigaluppi E, Lampasona V, Bingley PJ, Rogge L, Pastore MR, Bognetti E, Bottazzo GF, Gale EAM, Bosi E (1995) Islet autoantibody markers in IDDM: Risk assessment strategies yielding high sensitivity. Diabetologia 38: 816-822.

30. Kasuga A, Ozawa Y, Suzuki R, Maruyama T, Saruta $T$ (1996) Single radioligand binding assay for GAD65 and IA-2 autoantibodies. Tounyoubyou (Diabetes) 39: 659-662 (In Japanese).
31. Notkins AL, Lu J, Li Q, VanderVegt FP, Wasserfall C, Maclaren NK, Lan MS (1996) IA-2 and IA-2 beta are major autoantigen in IDDM and the precursors of the $40 \mathrm{kDa}$ and $37 \mathrm{kDa}$ tryptic fragments. $J$ Autoimmunity 9: 677-682.

32. Kobayashi T, Kajio H, Tamemoto K, Sugimoto T, Nakanishi K, Murase T, Kato N, Kosaka K, Okubo $M$ (1993) Immunogenetic and clinical characterization of slowly progressive IDDM. Diabetes Care 16: 780-788.

33. Kasuga A, Ozawa Y, Maruyama T, Ishihara T, Amemiya S, Saruta T (1997) Autoantibody against ICA512 did not improve test sensitivity for slowly progressive IDDM in adults. Diabetes Care 20: 679680 . 